\title{
Antioxidant system response induced by aluminum in two rice cultivars
}

\section{Cleberson Ribeiro ${ }^{1 *}$, José Cambraia1, Paulo Henrique Pereira Peixoto², Élcio Meira da Fonseca Júnior ${ }^{1}$}

${ }^{1}$ Departamento de Biologia Geral, Universidade Federal de Viçosa, Viçosa, MG, Brasil.

²Departamento de Botânica, Instituto de Ciências Biológicas, Universidade Federal de Juiz de Fora, Juiz de Fora, MG, Brasil.

*Corresponding author: cleberson.ribeiro@ufv.br

Received: May 10, 2012; Accepted: July 3, 2012

\begin{abstract}
The antioxidant defense system response was evaluated in two rice cultivars (Oryza sativa L.), Fernandes (CNA-1158) and Maravilha (CNA-6843-1), treated with toxic levels of aluminum. After exposure to aluminum we determined plant growth, $\mathrm{H}_{2} \mathrm{O}_{2}$ and $\mathrm{O}_{2}^{-*}$ contents, lipid peroxidation, antioxidant enzymes activities and ascorbate and dehydroascorbate contents. Al predominantly accumulated in roots of both cultivars but it reduced root and shoot growth only in the Maravilha cultivar. Treatment with aluminum resulted in a reduction of 84 and $60 \%$ in the levels of $\mathrm{H}_{2} \mathrm{O}_{2}$ in the roots of the cultivars Maravilha and Fernandes, respectively, and of $26 \%$ in the levels of $\mathrm{O}_{2}{ }^{--}$only in the roots of Fernandes cultivar. Increased lipid peroxidation was observed only in the roots of the Maravilha cultivar. In general, the antioxidant enzyme activities were higher in roots and increased in the presence of aluminum, especially in the Fernandes cultivar. The levels of ascorbate were higher in leaves and increased with aluminum treatment, while dehydroascorbate decreased in roots of both cultivars after aluminum treatment. However, the ascorbate/dehydroascorbate ratio increased in the roots of both cultivars after treatment with aluminum. Ascorbate, dehydroascorbate and ascorbate/dehydroascorbate levels found here point to an efficient regeneration of ascorbate, essential for the homeostasis of cellular metabolites involved in reactive oxygen species removal by rice plants treated with aluminum. Therefore, the higher tolerance of Fernandes to aluminum relative to Maravilha cultivar may be the result of better growth of the root system and shoots, higher antioxidant enzyme activities and a best use/ regeneration of ascorbate.
\end{abstract}

Keywords: aluminum, enzymes, reactive oxygen species, Oryza sativa, oxidative stress.

Abbreviations: AA: ascorbic acid; Al: aluminum; APX: ascorbate peroxidase; CAT: catalase; DHA: dehydroascorbic acid; DHAR: dehydroascorbate reductase; DTT: ditiothreitol; GPX: glutathione peroxidase; GR: glutathione reductase; GSH: reduced glutathione; GSSG: oxidized glutathione; MDHA: monodehydroascorbate; NBT: nitro blue tetrazolium; POX, peroxidase; PMSF: phenylmethanesulfonyl fluoride; PVPP: polyvinylpyrrolidone; ROS: reactive oxygen species; SOD: superoxide dismutase; TBA: thiobarbituric acid; TCA: trichloroacetic acid. 


\section{INTRODUCTION}

The toxicity of $\mathrm{Al}$ in plants is considered one of the main factors that limit plant productivity in acidic soils (Kochian, 1995; Vitorello et al. 2005). About $60 \%$ of the total acid soils in the world are in the tropical and subtropical regions (Kochian et al., 2004). Al, after being absorbed by root cells, tends to accumulate preferentially in the root apex, promoting inhibition of root elongation and cell division (Kochian, 1995; Arroyave et al., 2011).

This element can react with many sites in cells that are potential targets of its injury, including the cell wall, plasma membrane, cytoskeleton and nucleus, triggering a series of effects that characterize its toxicity (Kochian et al., 2004; Vitorello et al., 2005; Arroyave et al., 2011). In addition, at toxic levels, Al is able to modify plant metabolism and change the redox state of cellular components, inducing the production of ROS, which can result in oxidative stress (Richards et al., 1998; Ezaki et al., 2000; Achary et al., 2008; Pereira et al., 2010; Ma et al., 2012).

ROS are partially reduced forms of molecular oxygen, highly reactive and considered inevitable subproducts from aerobic metabolism (Gratão et al., 2005). The main forms are superoxide anion $\left(\mathrm{O}_{2}^{--}\right)$, hydrogen peroxide $\left(\mathrm{H}_{2} \mathrm{O}_{2}\right)$, hydroxyl radical $\left({ }^{\circ} \mathrm{OH}\right)$ and singlet oxygen $\left({ }^{1} \mathrm{O}_{2}\right)$; they are produced in different cellular compartments, including chloroplasts, mitochondria, peroxisomes and apoplast (Gratão et al., 2005; Edreva, 2005).

Biotic and abiotic can cause an imbalance in cellular homeostasis, which results in increased production and accumulation of ROS in plant tissues (Gratão et al., 2005). Recent research suggests that at least part of Al toxicity is due to oxidative stress caused by this ion; therefore, the tolerance of plants to Al may be related to the activity of the plants' antioxidant systems (Sharma and Dubey, 2007; Giannakoula et al., 2010; Panda and Matsumoto, 2010; Ma et al., 2012; Xu et al., 2012). This system involves enzymatic and non-enzymatic antioxidant mechanisms for removal of ROS produced during oxidative stress (Gratão et al., 2005). The main enzymes involved in the homeostatic control of the levels of $\mathrm{H}_{2} \mathrm{O}_{2}$ and $\mathrm{O}_{2}{ }^{-}$in plant metabolism are SOD, CAT, POX, APX and GPX (Gratão et al., 2005). The antioxidative enzyme SOD is considered the first line of defense in combating ROS, transmuting $\mathrm{O}_{2}{ }^{--}$to form $\mathrm{H}_{2} \mathrm{O}_{2}$. However, the enzymes CAT, POX, APX and GPX complement the process of ROS elimination by transforming $\mathrm{H}_{2} \mathrm{O}_{2}$ into water and molecular oxygen (Gratão et al., 2005). Among the metabolites that participate in the non-enzymatic defense system are AA,
GSH, $\alpha$-tocopherol and carotenoids (Gratão et al., 2005). AA and GSH are powerful antioxidants that directly react with various types of ROS (Foyer and Noctor, 2011; $X u$ et al., 2012) and/or serve as electron donors for key enzymes of the antioxidant enzymatic system such as APX and GPX (Noctor et al., 2012). The joint action of both the enzymatic and non-enzymatic antioxidant defense systems allows for plants to efficiently combat the excess ROS generated under conditions of oxidative stress induced by biotic or abiotic stressors.

In this study, the responses of both the enzymatic and non-enzymatic antioxidant systems to oxidative stress induced by $\mathrm{Al}$ in two rice cultivars were investigated. Such responses were used to explain the differences in tolerance capacity between the cultivars.

\section{MATERIAL AND METHODS}

Plant material and growth conditions: For this study, we used two rice cultivars (Oryza sativa L.) with different tolerances to Al: Fernandes (CNA-1158) and Maravilha (CNA-6843-1), which are considered tolerant and sensitive to Al, respectively. These were provided by Embrapa (acronym for Empresa Brasileira de Pesquisa Agropecuária - National Research Center for Rice and Beans).

The seeds of the two cultivars, selected by size and shape, were surface sterilized with sodium hypochlorite $3 \%(\mathrm{v} / \mathrm{v})$ for $15 \mathrm{~min}$ and then washed in running water and rinsed in deionized water. The seeds were germinated in germitest paper rolls dipped in Clark nutrient solution (Clark, 1975), pH 4.0, with one third of the original ionic strength under continuous aeration. After 9 days, seedlings were selected for uniformity of size and shape and transplanted into polyethylene pots containing $1.8 \mathrm{~L}$ of Clark nutrient solution (Clark, 1975), pH 4.0, and treated with Al concentrations of 0 and $1.0 \mathrm{mM}$, applied as $\mathrm{AlCl}_{3}$. The experiment was conducted in a growth room with controlled temperature $\left(25 \pm 3^{\circ} \mathrm{C}\right)$, photosynthetically active radiation flux of $230 \mu \mathrm{mol} \mathrm{m} \mathrm{m}^{-2} \mathrm{~s}^{-1}$ and a photoperiod of 16 hours. The nutrient solution was continuously aerated, with the $\mathrm{pH}$ adjusted daily to 4.0 , and the solution was renewed after 5 days of plant growth.

Ten days after treatment with Al, the plants were harvested, washed in running water and rinsed in deionized water. We then determined the length of the main root and shoots and their fresh weights. Then samples were taken for the various chemical and enzymatic analyses. 
Determination of the aluminum content: Samples of oven-dried plant materials, finely ground in a stainless steel electric grinder, were digested in a mixture of $\mathrm{HNO}_{3}: \mathrm{HClO}_{4}(2: 1, \mathrm{v} / \mathrm{v})$, and the $\mathrm{Al}$ content was determined using the aluminon spectrophotometric method (Wang and Wood, 1973).

Determination of $\mathrm{O}_{2} \cdot \mathrm{H}_{2} \mathrm{O}_{2}$ and lipid peroxidation: For the determination of $\mathrm{O}_{2}^{--}$content, roots and leaves were cut into small segments and placed in $2 \mathrm{~mL}$ of a reaction medium consisting of $20 \mathrm{mM}$ sodium phosphate buffer, $\mathrm{pH} 7.8,0.1 \mathrm{mM} \mathrm{Na} \mathrm{N}_{2}$ EDTA and 20 $\mu \mathrm{M}$ NADH (Mohammadi and Karr, 2001). The reaction was started by adding $100 \mu \mathrm{L}$ of $25.2 \mathrm{mM}$ epinephrine (freshly prepared in $0.1 \mathrm{~N} \mathrm{HCl}$ ) in sealed tubes. After incubation at $28^{\circ} \mathrm{C}$ for $5 \mathrm{~min}$, the plant tissue fragments were removed, and the absorbance was measured at $480 \mathrm{~nm}$ for $5 \mathrm{~min}$. The amount of adrenochrome formed was estimated using a molar extinction coefficient of 4.0 $10^{3} \mathrm{M}^{-1} \mathrm{~cm}^{-1}$ (Boveris, 1984).

For the determination of $\mathrm{H}_{2} \mathrm{O}_{2}$, plant tissue samples were macerated in liquid nitrogen and homogenized in $2 \mathrm{~mL}$ of $50 \mathrm{mM}$ potassium phosphate buffer, $\mathrm{pH} 6.5$, containing $1 \mathrm{mM}$ hydroxylamine. After filtration, the homogenate was centrifuged at $10,000 g_{n}$ for $15 \mathrm{~min}$ at $4^{\circ} \mathrm{C}$. Aliquots of $100 \mu \mathrm{L}$ of the supernatant were added to $1.9 \mathrm{~mL}$ of a reaction medium consisting of $250 \mu \mathrm{M}$ $\mathrm{FeNH}_{4}\left(\mathrm{SO}_{4}\right), 25 \mathrm{mM}$ sulfuric acid, $250 \mu \mathrm{M}$ xylenol orange and $100 \mathrm{mM}$ sorbitol. After $30 \mathrm{~min}$ in the dark, the absorbance of the samples was determined at 560 $\mathrm{nm}$ (Gay and Gebicki, 2000). The levels of $\mathrm{H}_{2} \mathrm{O}_{2}$ were estimated based on a calibration curve prepared with authentic $\mathrm{H}_{2} \mathrm{O}_{2}$ standards.

The intensity of lipid peroxidation in roots and leaves was estimated by the concentration of malonaldehyde produced after reaction with TBA (Cakmak; Horst, 1991). The tissue was homogenized in $2 \mathrm{~mL}$ of $1 \%(\mathrm{w} / \mathrm{v})$ TCA and centrifuged at $12,000 \mathrm{~g}_{\mathrm{n}}$ for $15 \mathrm{~min}$ at $4^{\circ} \mathrm{C}$. Aliquots of the supernatant were added to $1.5 \mathrm{~mL}$ of a solution of $0.5 \%$ TBA (w/v) in 20\% TCA (w/v) and incubated in a water bath at $95^{\circ} \mathrm{C}$. After $30 \mathrm{~min}$, the reaction was stopped, the tubes were centrifuged at $10,000 g_{n}$ for $10 \mathrm{~min}$, and the absorbance of the supernatant was determined at 532 and $600 \mathrm{~nm}$. The concentration of malonic aldehydeTBA complex was estimated using a molar absorptivity coefficient of $155 \mathrm{mM}^{-1} \mathrm{~cm}^{-1}$.

Enzyme assays: To determinate enzyme activities, samples of approximately $0.3 \mathrm{~g}$ of roots or leaves were ground in liquid nitrogen and homogenized in the following media:
- $\quad 0.1 \mathrm{M}$ potassium phosphate buffer, pH6.8,0.1 mM EDTA, $1 \mathrm{mM}$ PMSF and $1 \%$ (w/v) PVPP for the enzymes CAT (EC 1.11.1.6), POX (EC 1.11.1.7), APX (EC 1.11.1.11) and SOD (EC 1.15.1.1) (Peixoto et al., 1999);

- $\quad 0.1 \mathrm{M}$ Tris-HCl buffer, pH 7.5, $1 \mathrm{mM}$ EDTA and $10 \mathrm{mM}$ $\mathrm{MgCl}_{2}$ (Nagalakshmi and Prasad, 2001) for the GPX (EC 1.11.1.9);

- $\quad 0.1 \mathrm{M}$ potassium phosphate buffer, pH 7.5, 1 mM EDTA, $2 \mathrm{mM}$ DTT, $1 \mathrm{mM}$ PMSF and 1\% PVPP for the enzyme GR (EC 1.6.4.2) (Carlberg and Mannervik, 1985).

After filtration through 4 layers of cheesecloth, the homogenates were centrifuged at $12,000 g_{n}$ for $15 \mathrm{~min}$ at $4^{\circ} \mathrm{C}$, and the supernatants were used as the source of enzyme.

Enzyme activities were determined by adding $0.1 \mathrm{~mL}$ of enzyme extract to $2.9 \mathrm{~mL}$ of reaction medium consisting of:

- $25 \mathrm{mM}$ potassium phosphate buffer, pH 6.8, $20 \mathrm{mM}$ pyrogallol and $20 \mathrm{mM} \mathrm{H}_{2} \mathrm{O}_{2}$ for POX;

- $50 \mathrm{mM}$ potassium phosphate buffer, pH 7.0 and $12.5 \mathrm{mM} \mathrm{H}_{2} \mathrm{O}_{2}$ for CAT;

- $50 \mathrm{mM}$ potassium phosphate buffer, pH 6.0, AA $0.8 \mathrm{mM}$ and $1 \mathrm{mM} \mathrm{H}_{2} \mathrm{O}_{2}$ for APX (Peixoto et al., 1999).

Enzyme activities were determined by adding $0.1 \mathrm{~mL}$ of enzyme extract to $0.9 \mathrm{~mL}$ of reaction medium consisting of:

- $\quad 0.1 \mathrm{M}$ potassium phosphate buffer, pH 7.5,1 mM EDTA, $1 \mathrm{mM} \mathrm{GSSG}$ and $0.1 \mathrm{mM}$ NADPH for GR (Carlberg; Mannervik, 1985);

- $50 \mathrm{mM}$ potassium phosphate buffer, pH 7.0, $1 \mathrm{mM}$ EDTA, $0.1 \mathrm{mM} \mathrm{NaCl}, 1 \mathrm{mM}$ GSH, $0.2 \mathrm{mM} \mathrm{NADPH}, 0.25 \mathrm{mM} \mathrm{H}_{2} \mathrm{O}_{2}$ and 1 unit of GR for GPX (Nagalakshmi; Prasad, 2001).

In all cases, the enzyme activities were estimated by measuring the absorbance change during the first minute of the reaction, at $30^{\circ} \mathrm{C}$. Enzyme activities were estimated using the following molar extinction coefficients: POX (420 nm; ع: $\left.2.47 \mathrm{mM}^{-1} \mathrm{~cm}^{-1}\right)$; CAT (240 nm, $\varepsilon: 36 \mathrm{M}^{-1} \mathrm{~cm}^{-1}$ ); APX (290 nm, ع: $\left.2.8 \mathrm{mM}^{-1} \mathrm{~cm}^{-1}\right)$; GPX $(340 \mathrm{~nm}$, ع: $\left.9.6 \mathrm{mM}^{-1} \mathrm{~cm}^{-1}\right)$; and GR $\left(340 \mathrm{~nm}, \varepsilon: 6.22 \mathrm{mM}^{-1} \mathrm{~cm}^{-1}\right)$.

The SOD activity was determined by adding $30 \mu \mathrm{L}$ of crude enzyme extract to a reaction medium constituted of 50 $\mathrm{mM}$ sodium phosphate buffer, $\mathrm{pH} 7.8,13 \mathrm{mM}$ methionine, $75 \mathrm{mM}$ p-NBT, $0.1 \mathrm{mM}$ EDTA and $2 \mu \mathrm{M}$ riboflavin. The 
reaction was conducted at $25^{\circ} \mathrm{C}$ in a reaction chamber under illumination of a $15 \mathrm{~W}$ fluorescent lamp. After $5 \mathrm{~min}$ of exposure to light, the illumination was interrupted, and the blue formazan produced by photoreduction of NBT was measured at $560 \mathrm{~nm}$ (Giannopolitis; Ries, 1977). One unit of SOD was defined as the amount of enzyme required to inhibit NBT photoreduction by $50 \%$.

The protein content of the enzyme extracts was determined by the method of Lowry et al. (1951) and using BSA as the standard.

Determination of the levels of ascorbate and dehydroascorbate: To determine the levels of $A A$ and DHA, samples of leaf and root tissue were homogenized in $2 \mathrm{~mL}$ of $6 \%$ TCA $(\mathrm{w} / \mathrm{v})$, filtered and then centrifuged at $15,000 g_{\mathrm{n}}$ for $5 \mathrm{~min}$ at $4^{\circ} \mathrm{C}$ (Kampfenkel et al., 1995). The total content of ascorbate (AA + DHA) was determined in aliquots of extracts treated with $0.5 \mathrm{mM}$ DTT and $0.02 \mathrm{M}$ sodium phosphate buffer, $\mathrm{pH} 7.4$, at $42^{\circ} \mathrm{C}$ for $15 \mathrm{~min}$. Then $0.025 \% \mathrm{~N}$-ethylmaleimide (w/v), 2.5\% TCA (w/v), $8.4 \%$ $\mathrm{H}_{3} \mathrm{PO}_{4}(\mathrm{v} / \mathrm{v}), 0.8 \% 2,2$ '-dipyridyl (w/v) and $0.3 \% \mathrm{FeCl}_{3}$ $(\mathrm{w} / \mathrm{v})$ were added and incubated again at $42^{\circ} \mathrm{C}$ for $40 \mathrm{~min}$. After stopping the reaction on ice, the absorbance was measured at $525 \mathrm{~nm}$. The AA content was determined as described above, but omitting DTT and N-ethylmaleimide. The DHA content was calculated as the difference between the total content of ascorbate $(A A+D H A)$ and the content of the reduced form $(A A)$.

Statistical analysis: The treatments were arranged in a randomized block design, according to factorial design with three replicates. The results were submitted to analysis of variance and means were compared using the Tukey test at $5 \%$ probability.

\section{RESULTS}

Growth in length and fresh mass yield in both root and shoot of the Maravilha cultivar (Al-sensitive cultivar) were reduced by $\mathrm{Al}$ treatment (Figures $1 \mathrm{~A}$ and $\mathrm{B}$ ). However, the cultivar Fernandes (Al-tolerant cultivar) did not display any significant changes in the growth of the two parts of the plant, and the values of these parameters were always higher than those of the Maravilha cultivar, regardless of the presence of $\mathrm{Al}$ (Figures $1 \mathrm{~A}$ and $\mathrm{B}$ ).

On average, the levels of $\mathrm{Al}$ in the roots increased seven times in both cultivars after treatment with this metal (Figure 1C). In the shoot, the Al content increased only in the sensitive cultivar.
Peroxidation of lipids in the roots of the Al-sensitive cultivar increased $13 \%$ after treatment with Al, while in the Al-tolerant cultivar, no significant effect was observed (Figure 1D). In the leaves, Al did not modify the amount of lipid peroxidation in either of the cultivars, although it was higher in the Al-tolerant cultivar regardless of the presence of Al (Figure 1D). The amount of lipid peroxidation in leaves was always higher than in roots.

Al treatment caused a reduction in the levels of $\mathrm{O}_{2}$ only in the roots of the Fernandes cultivar (Figure 1E). In the leaves, the reduction in $\mathrm{O}_{2}^{-}$was observed in both cultivars, especially in the Fernandes cultivar.

Al treatment significantly reduced $\mathrm{H}_{2} \mathrm{O}_{2}$ levels in the roots of both cultivars, especially in the Maravilha cultivar (Figure 1F). In the leaves, the $\mathrm{H}_{2} \mathrm{O}_{2}$ levels were not modified by treatment with $\mathrm{Al}$ in either of the rice cultivars. Notably, control plants of the Maravilha cultivar showed $\mathrm{H}_{2} \mathrm{O}_{2}$ levels that were $43 \%$ higher than of the Fernandes cultivar.

The SOD activity did not change in the roots of the Alsensitive cultivar but increased $17 \%$ in the roots of the Al-tolerant cultivar after treatment with Al (Figure 2A). In leaves, we observed an 11\%-decrease in SOD activity in the Al-sensitive cultivar, while no effect on the Al-tolerant cultivar was observed. Regardless of the presence of $\mathrm{Al}$, SOD activity was higher in roots than in leaves.

The activity of CAT in roots of Al-treated plants increased by $43 \%$ and $24 \%$ in the Maravilha and Fernandes cultivars, respectively (Figure 2B). In the leaves, the activity of this enzyme was not modified by treatment with Al in either cultivar. However, the CAT activity was higher in the Al-tolerant cultivar than in the sensitive one.

The POX activity in roots increased 45 and $33 \%$ in the Maravilha and Fernandes cultivars, respectively, after treatment with $\mathrm{Al}$ (Figure 2C). In contrast, a reduction of 22 and $23 \%$ in POX activity in the leaves was observed in the sensitive and tolerant cultivars, respectively. The activity of this enzyme in the roots was, on average, about ten times higher than in the leaves.

The APX activity was not changed by treatment with Al in roots and leaves in either cultivar (Figure 2D). However, the activity of this enzyme was always higher in Al-tolerant cultivar, regardless of the part of the plant analyzed. The activity of APX in the roots was, on average, about four times higher than in the leaves.

Treatment with Al resulted in increases of 25 and $32 \%$ in GR activity in the roots of the Maravilha and Fernandes 

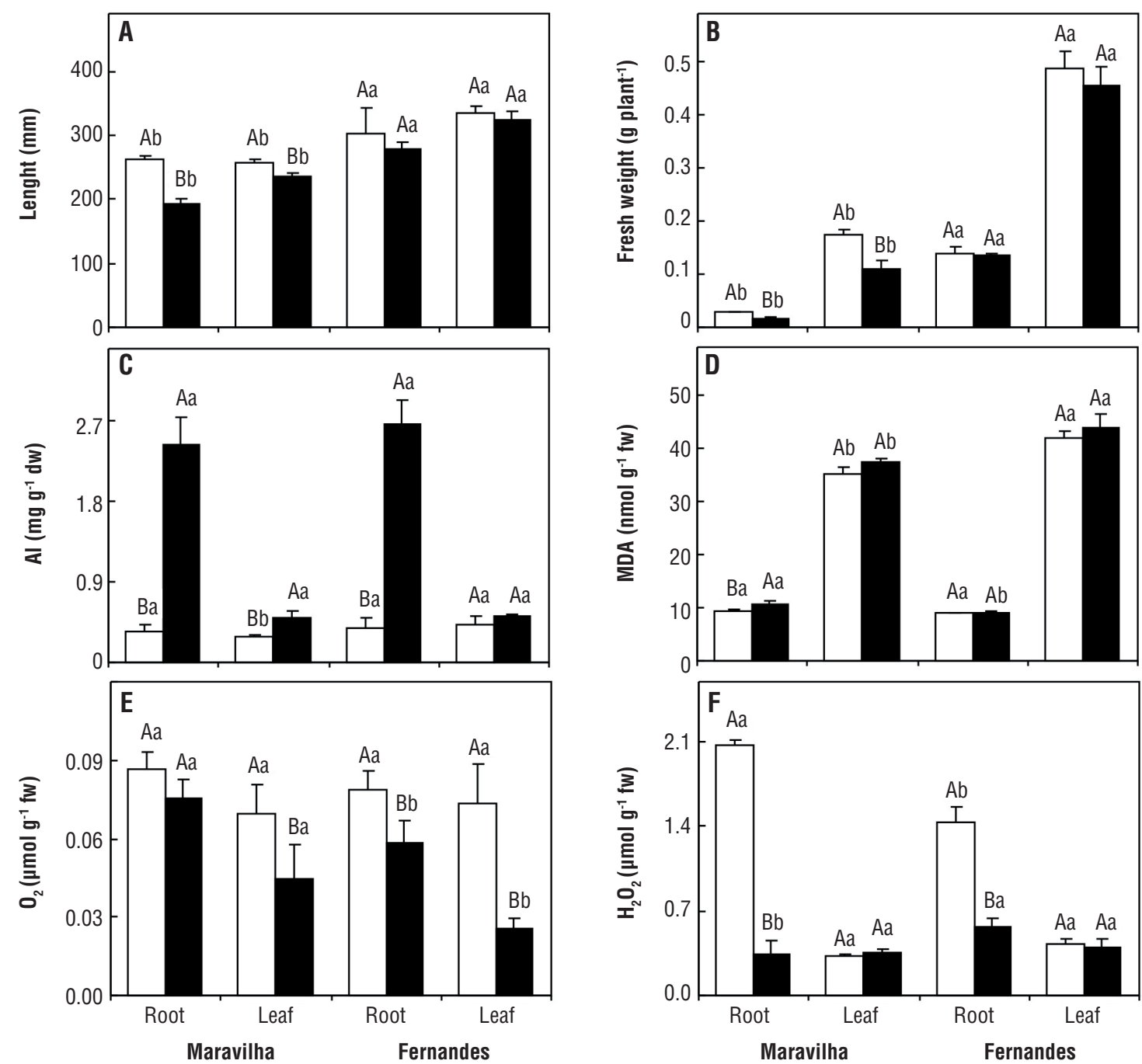

Figure 1. Length $(A)$, fresh weight $(B)$, levels of aluminum $(C)$, lipid peroxidation $(D)$ superoxide anion $(E)$ and hydrogen peroxide $(F)$ content in root and leaf of two rice cultivars after 10 days of exposure to $0 \mathrm{mM}(\square)$ and $1 \mathrm{mM}(\boldsymbol{\square})$ of aluminum. Means followed by the same capital letter in the levels of aluminum for the same cultivar and the same letter among cultivars for the same level of aluminum do not differ $(p \leq 0.05)$. Bars represent the standard deviation $(n=3)$.

cultivars, respectively (Figure 2E). However, in the leaves, this enzyme did not significantly change in either cultivar. The GR activity was higher in roots than in leaves in both cultivars.

The GPX activity in roots of Al treated plants increased by $13 \%$ and $38 \%$ in the Maravilha and Fernandes cultivars, respectively (Figure 2F). Under this condition, the activity of this enzyme in the roots of the Al-tolerant cultivar was $31 \%$ higher than in the sensitive one. In the leaves, treatment with $\mathrm{Al}$ resulted in a $10 \%$ reduction in the activity of this enzyme only in the Al-sensitive cultivar. The GPX activity was always higher in roots than in leaves.
The AA content in the roots was not changed by treatment with $\mathrm{Al}$, while increases of 18 and $19 \%$ were observed in the leaves of the Maravilha and Fernandes cultivars, respectively (Figure $3 \mathrm{~A}$ ). Treatment with Al resulted in decreases of 40 and $53 \%$ in DHA in the roots of Al-sensitive and Al-tolerant cultivars, respectively, while no effects were observed in the leaves (Figure 3B). The total ascorbate content decreased 60 and $72 \%$ in the roots of Al-sensitive and Al-tolerant cultivars, respectively, after treatment with Al (Figure $3 \mathrm{C}$ ). In leaves, Al increased the total ascorbate content by 22 and $12 \%$ in Al-sensitive and Al-tolerant cultivars, respectively. The 

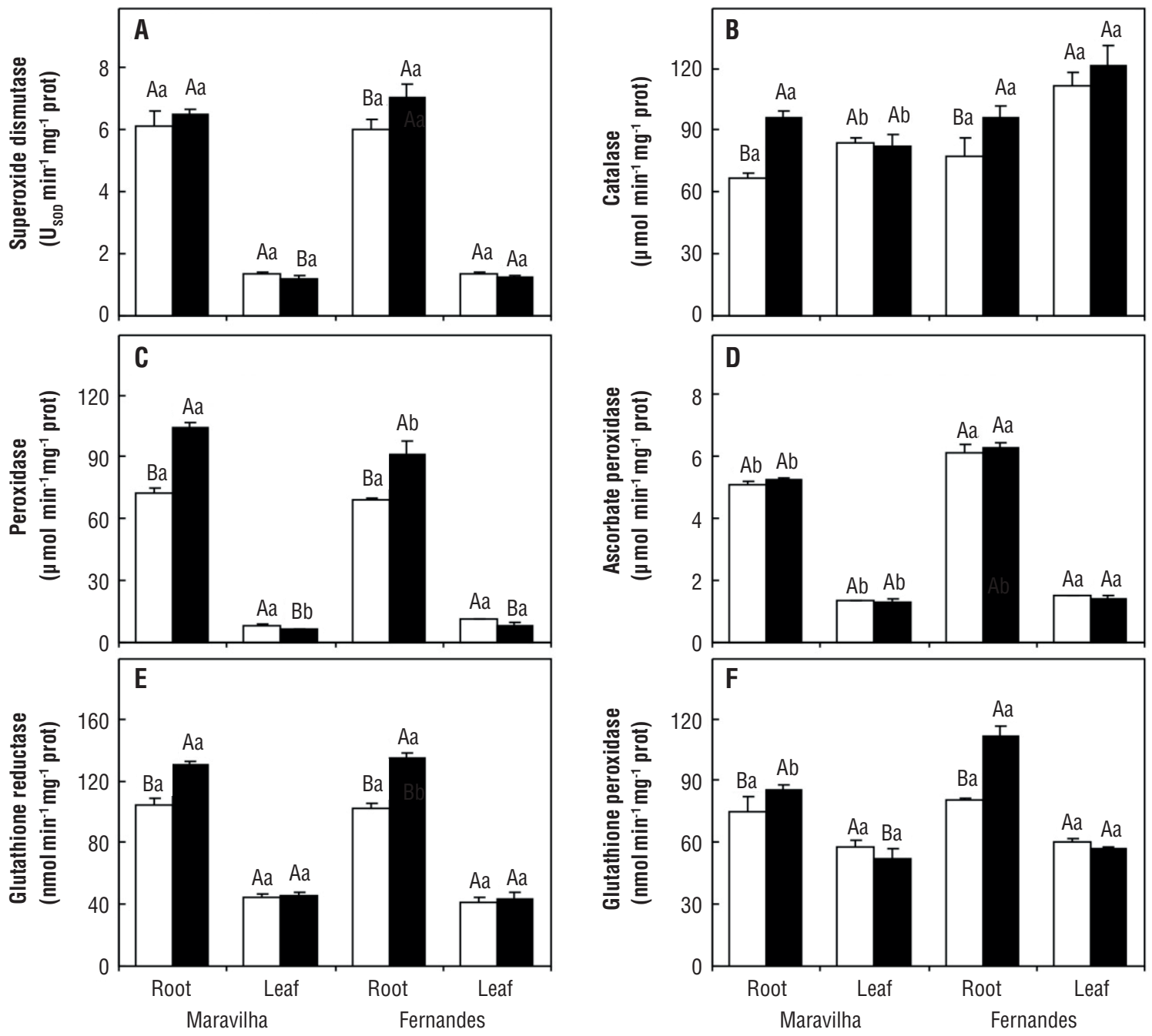

Figure 2. Activity of antioxidative enzymes in root and leaf of two rice cultivars after 10 days of exposure to $0 \mathrm{mM}(\square)$ and $1 \mathrm{mM}(\boldsymbol{\square})$ of aluminum. Means followed by the same capital letter in the levels of aluminum for the same cultivar and the same letter among cultivars for the same level of aluminum do not differ $(p \leq 0.05)$. Bars represent the standard deviation $(n=3)$.

AA/DHA ratio was unchanged in leaves of both rice cultivars after exposure to $\mathrm{Al}$; however, there were increases of $48 \%$ and $115 \%$ in this ratio in the roots of Al-sensitive and Al-tolerant cultivars, respectively (Figure 3D).

\section{DISCUSSION}

A growing body of evidence suggests that oxidative stress is a key factor in the damage observed in plants exposed to biotic and abiotic stresses, including Al toxicity (Sharma and Dubey, 2007; Achary et al., 2008; Panda and Matsumoto, 2010; Pereira et al., 2010; Ma et al., 2012).
The production of ROS induced by $\mathrm{Al}$ is well-known (Yamamoto et al., 2002; Achary et al., 2008; Xu et al., 2012), although the role of oxidative stress in Al toxicity is still unclear. Although Al is not a transition element and does not participate in redox reactions, it has pro-oxidant activity (Exley, 2004), promoting increased concentration of ROS and changing the redox state of the metabolic system in cells (Achary et al., 2008; Ma et al., 2012; Xu et al., 2012). However, in tolerant plants, even in the presence of toxic levels of Al, the levels of ROS in plant tissues do not significantly change, indicating the existence of efficient antioxidant defense systems to this metal (Giannakoula et al., 2010). 

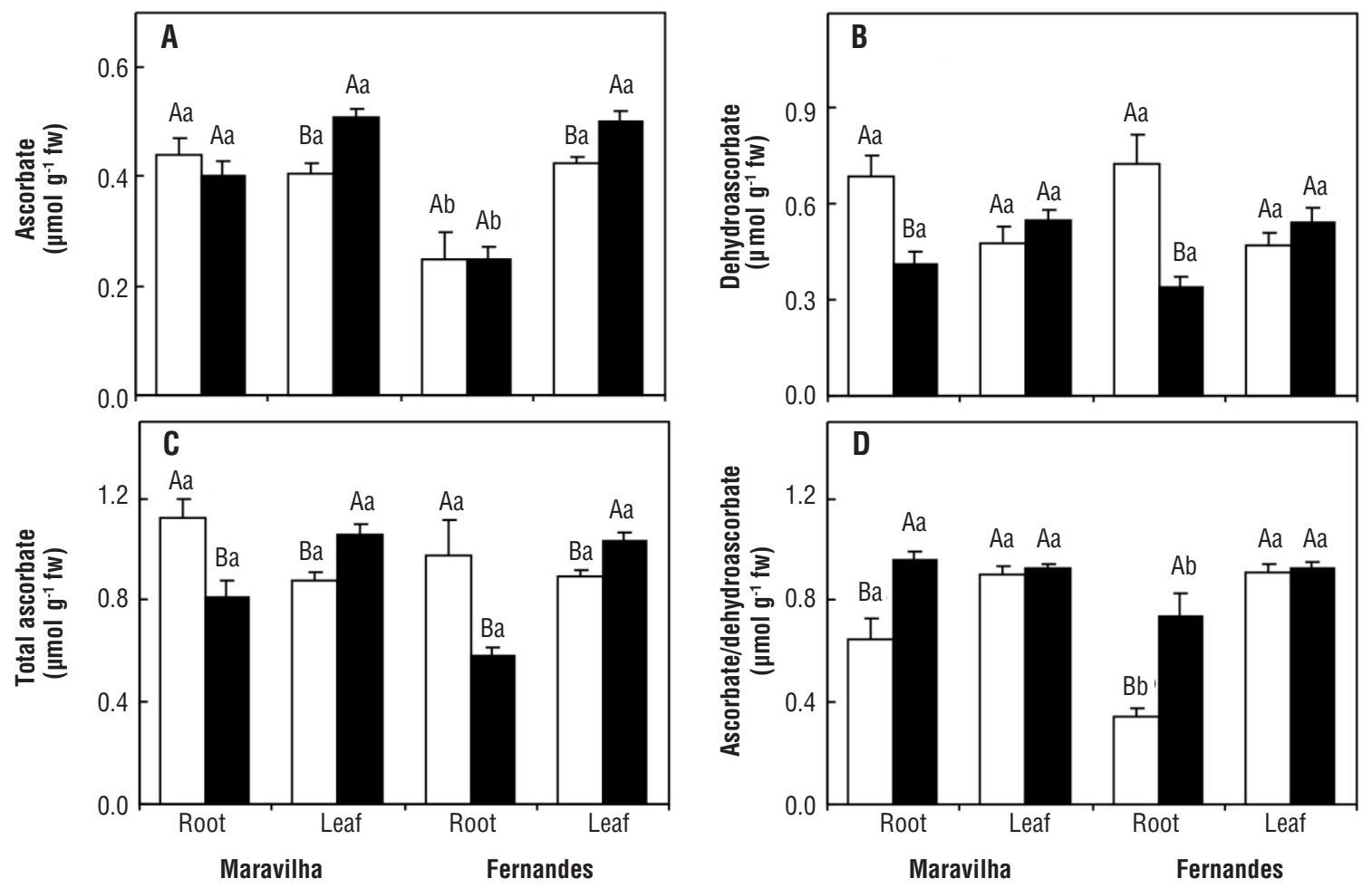

Figure 3. Levels of ascorbate, dehydroascorbate, total ascorbate and ascorbate/dehydroascorbate ratio in root and leaf of two rice cultivars after 10 days of exposure to $0 \mathrm{mM}(\square)$ and $1 \mathrm{mM}(\boldsymbol{\square})$ of aluminum. Means followed by the same capital letter in the levels of aluminum for the same cultivar and the same letter among cultivars for the same level of aluminum do not differ ( $p \leq 0.05)$. Bars represent the standard deviation $(n=3)$.

The two rice cultivars used in this study originate from Central Brazil, where soils are acidic and have high levels of Al (Lopes, 1984). They are comparatively more tolerant to $\mathrm{Al}$ than the Asian varieties used by Sivaguru and Paliwal (1993) and Ganesan et al. (1993). In this study, we aimed to verify whether these cultivars, like other rice cultivars (Meriga et al. 2004; Sharma and Dubey, 2007; Meriga et al. 2010; Ma et al. 2012) and other species (Cakmak and Horst, 1991; Peixoto et al., 1999; Boscolo et al., 2003; Dipierro et al., 2005; Achary et al., 2008), suffer from oxidative stress in the presence of toxic levels of Al and how this toxic element influences the activity of antioxidant enzymes and the balance of the ascorbate system.

Al predominantly accumulated in the roots of both rice cultivars, confirming previous results (Mendoça et al., 2003; Meriga et al., 2004; Sharma; Dubey, 2007; Meriga et al., 2010). Due to the higher accumulation of $\mathrm{Al}$ in the roots, the phytotoxic effects of $\mathrm{Al}$ are also more intense in this part of the plant, but they do extend to other plant parts later (Vitorello et al., 2005). Although the levels of Al were similar in both cultivars, the damage to the Al- sensitive cultivar was considerably more intense. In the Al-tolerant cultivar, no change in growth was observed, while in the Maravilha cultivar, a severe reduction in the growth of roots and shoots was observed. Similar results were described by Mendonça et al. (2005) and Justino et al. (2006) with the same rice cultivars and the same concentration of $\mathrm{Al}$ in the present work.

The plasma membrane is considered a major target of the phytotoxic effects of Al. Al can bind to phospholipids and/or modify the fatty acid composition of the plasma membrane, reducing its fluidity and increasing its permeability (Peixoto et al., 2001; Vitorello et al., 2005). Moreover, Al can cause oxidative stress, resulting in the production and accumulation of ROS, which cause peroxidation of membrane lipids (Meriga et al., 2004; Sharma and Dubey, 2007; Ma et al., 2012; Xu et al., 2012). Contrary to our expectations, in this study, the exposure of plants to $\mathrm{Al}$ resulted in a decrease in the levels of the two ROS analyzed, especially $\mathrm{H}_{2} \mathrm{O}_{2}$. The reductions in $\mathrm{O}_{2}{ }^{--}$and $\mathrm{H}_{2} \mathrm{O}_{2}$ observed in the roots of the Fernandes cultivar and $\mathrm{H}_{2} \mathrm{O}_{2}$ levels observed in the roots of the Maravilha cultivar after exposure to Al (Figure 1C) may 
be the result of consumption of these ROS in oxidation processes such as lipid peroxidation (Figure 1D), but is probably due to an increase in the activity of enzymes of the antioxidant defense system (Figure 2). Results like these have been observed in studies with other rice cultivars treated with toxic levels of Al (Kuo and Kao, 2003; Sharma and Dubey, 2007; Wang and Kao, 2007) and have been implicated in the mechanism of Al tolerance. There is also the possibility of a reaction between $\mathrm{O}_{2}{ }^{--}$and $\mathrm{H}_{2} \mathrm{O}_{2}$ in the presence of endogenous Fe (Cakmak and Horst, 1991), producing the $\mathrm{OH}^{-}$, the most important ROS form involved in lipid peroxidation (Achary et al., 2008). However, this seems unlikely since the increase in lipid peroxidation was small and observed only in the roots of the Al-sensitive genotype.

The increase in the activities of antioxidative enzymes in plants treated with Al was higher in roots than in leaves of both rice cultivars (Figure 2). This is probably a result of higher Al concentrations in roots (Figure $1 \mathrm{C}$ ) and may explain the lower rate of lipid peroxidation observed in this part of the plant (Figure 1D). The involvement of antioxidant enzymes is critical for the elimination of ROS. Apparently, this protection is the result of the joint action of several antioxidant enzymes rather than just one specific enzyme (Wang and Kao, 2007; Giannakoula et al., 2010; Pereira et al., 2010; Ma et al., 2012). A rapid and complete clearance of $\mathrm{O}_{2}{ }^{--}$and $\mathrm{H}_{2} \mathrm{O}_{2}$ is essential for the maintenance of cellular homeostasis since the reaction of these two ROS forms can result in the production of hydroxyl radicals $\left({ }^{\circ} \mathrm{OH}\right)$ via the Haber-Weiss reaction (Edreva, 2005). Reduced levels of lipid peroxidation found in the roots of both rice cultivars indicate that an efficient enzymatic defense system is working in their root cells. The amount of lipid peroxidation in the roots increased only $13 \%$ in the Maravilha cultivar but not in the Fernandes cultivar after treatment with Al (Figure 1D). The biological relevance of such change in lipid peroxidation requires further evaluation. Nevertheless, the Fernandes cultivar has an enzymatic defense system that is more effective in combating oxidative stress generated by $\mathrm{Al}$, confirming its greater tolerance to $\mathrm{Al}$ in comparison with the Maravilha cultivar. The greater tolerance of the Fernandes cultivar seems to be a result of the joint action of the enzymes SOD, APX and GPX. Similar to our results, Giannakoula et al. (2010) and Ma et al. (2012), working with two maize and rice cultivars with different tolerance to $\mathrm{Al}$, respectively, showed that the improvement in protection against $\mathrm{Al}$ toxicity was obtained by an increase in the activity of the antioxidant system.

Besides the antioxidative enzymes, metabolites such as GSH and AA can be used by plants for the elimination of excess ROS produced during oxidative stress (Gratão et al., 2005; Sharma; Dubey, 2007; Ma et al., 2012; Xu et al., 2012). Some of these ROS, such as $0_{2}{ }^{-*}$ and "singlet" oxygen, can be eliminated by direct reaction with AA through a non-enzymatic defense mechanism (Potters et al., 2002; Devi et al., 2003). Despite adequate levels of AA, $\mathrm{H}_{2} \mathrm{O}_{2}$ also needs the presence of enzymes such as APX to be eliminated (Potters et al., 2002). This reaction is considered the initial part of an important mechanism for removal of ROS in plants, called the ascorbateglutathione cycle (Gratão et al., 2005; Foyer and Noctor, 2011). APX uses AA as a substrate to produce MDHAs radicals, which can undergo spontaneous dismutation leading to DHA (Noctor et al., 2012). DHA can be regenerated to $A A$ through a reaction catalyzed by the DHAR enzyme, which uses GSH as a substrate for the reaction (Dipierro et al., 2005; Foyer and Noctor, 2011). In this study, there was a reduction in the levels of DHA in the roots of both rice cultivars after treatment with $\mathrm{Al}$ (Figure 3B). This result suggests that the DHAR enzyme is actively involved in the regeneration of $A A$ to maintain stable levels of this metabolite inside the cells, even after the imposition of stress by Al. Additionally, the AA/DHA ratio increased in the roots of cultivars after exposure to Al (Figure 3D), indicating that AA synthesis is reoccurring or that there is regeneration of this metabolite via catalysis by the DHAR enzyme, as suggested by Ishikawa et al. (2006). The second hypothesis seems more likely because the DHA levels (Figure 3B) were reduced after Al stress. Increased activity of the enzyme L-galactono1,4-lactone dehydrogenase may also have contributed to the increase in the AA/DHA ratio in the roots of the two rice cultivars after exposure to Al. The L-galactono-1,4lactone dehydrogenase, present in the inner membrane of mitochondria, is considered an important enzyme in the biosynthesis of AA in plants (Ishikawa et al., 2006; Foyer and Noctor, 2011). However, the activity of this enzyme was not evaluated in the present study.

In the literature, several authors consider the regeneration of $A A$ fundamental for cell homeostasis, allowing for re-use of AA in the removal of ROS (Aravind and Prasad, 2005; Wang and Kao, 2007; Ma et al., 2012; Xu et al., 2012). The reduction in the levels of DHA in the roots and the concomitant increase in the AA/DHA ratio (Figure 3D) occurred in parallel with the accumulation of $\mathrm{Al}$ in this part of the plant (Figure $1 \mathrm{C}$ ), indicating the involvement of this metabolite in the tolerance mechanism of these cultivars to excess Al.

The results indicate that greater tolerance to $\mathrm{Al}$ by the Fernandes cultivar in comparison with the Maravilha cultivar is the result of increased antioxidative enzyme activities and better use/regeneration of AA. 
Acknowledgements: The authors would like to thank the National Council for Scientific Development (CNPq) for the productivity scholarship and the Foundation for Research Support of Minas Gerais (FAPEMIG) for financial support.

\section{REFERENCES}

Achary VM, Jena S, Panda KK, Panda BB (2008) Aluminium induced oxidative stress and DNA damage in root cells of Allium cepa L. Ecotox. Environ. Saf. 70:300-310.

Aravind P, Prasad MNV (2005) Modulation of cadmium-induced oxidative stress in Ceratophyllum demersum by zinc involves ascorbateglutathione cycle and glutathione metabolism. Plant Physiol. Biochem. 43:107-116.

Arroyave C, Barcelo J, Poschenrieder C, Tolra R (2011) Aluminiuminduced changes in root epidermal cell patterning, a distinctive feature of hyperresistance to Al in Brachiaria decumbens. J. Inorg. Biochem. 105:1477-1483.

Boscolo PRS, Menossi M, Jorge RA (2003) Aluminum-induced oxidative stress in maize. Phytochemistry 62:181-189.

Boveris A (1984) Determination of the production of superoxide radicals and hydrogen peroxide in mitochondria. Methods Enzymol. 105:429-435.

Cakmak I, Horst WJ (1991) Effect of aluminium on lipid peroxidation, superoxide dismutase, catalase, and peroxidase activities in root tips of soybean (Glycine max). Physiol. Plant. 83:463-468.

Carlberg I, Mannervik B (1985) Glutathione reductase. Methods Enzymol. 113:484-495.

Clark RB (1975) Characterization of phosphatase of intact maize roots. J. Agric. Food. Chem. 23:458-460.

Devi SR, Yamamoto Y, Matsumoto H (2003) An intracellular mechanism of aluminum tolerance associated with high antioxidant status in cultured tobacco cells. J. Inorg. Biochem. 97:59-68.

Dipierro N, Mondelli D, Paciolla C, Brunetti G, Dipierro S (2005) Changes in the ascorbate system in the response of pumpkin (Cucurbita pepo L.) roots to aluminium stress. J. Plant Physiol. 162:529-536.

Edreva A (2005) Generation and scavenging of reactive oxygen species in chloroplasts: a submolecular approach. Agr. Ecosyst. Environ. 30:119-133.

Exley C (2004) The pro-oxidant activity of aluminum. Free. Radic. Biol. Med. 36:380-387.

Ezaki B, Gardner RC, Ezaki Y, Matsumoto H (2000) Expression of aluminuminduced genes in transgenic Arabidopsis plants can ameliorate aluminum stress and/or oxidative stress. Plant Physiol. 122:657-665.

Foyer CH, Noctor G (2011) Ascorbate and Glutathione: The Heart of the Redox Hub. Plant Physiol. 155:2-18.

Ganesan K, Sankaranarayanan C, Balakumar T (1993) Physiological basis of differential aluminum tolerance in rice genotypes. Comm. Soil Sci. Plant Anal. 24:2179-2191.

Gay C, Gebicki JM (2000) A critical evaluation of the effect of sorbitol on the ferric-xylenol orange hydroperoxide assay. Anal. Biochem. 284:217-220.
Giannakoula A, Moustakas M, Syros T, Yupsanis T (2010) Aluminum stress induces up-regulation of an efficient antioxidant system in the Al-tolerant maize line but not in the Al-sensitive line. Environ. Exp. Bot. 67:487-494.

Giannopolitis CN, Ries SK (1977) Superoxide dismutases: Occurrence in higher plants. Plant Physiol. 59:309-314.

Gratao PL, Polle A, Lea PJ, Azevedo RA (2005) Making the life of heavy metal-stressed plants a little easier. Funct. Plant Biol. 32:481-494.

Ishikawa T, Dowdle J, Smirnoff N (2006) Progress in manipulating ascorbic acid biosynthesis and accumulation in plants. Physiol. Plant. 126:343-355.

Justino GC, Cambraia J, Oliva MA, Oliveira JA (2006) Absorção e redução de nitrato em duas cultivares de arroz na presenca de alumínio. Pesq. Agropec. Bras. 41:1285-1290.

Kampfenkel K, Montagu MV, Inze D (1995) Extraction and determination of ascorbate and dehydroascorbate from plant tissue. Anal. Biochem. Meth. Biol. Sci. 225:165-167.

Kochian LV (1995) Cellular mechanisms of aluminum toxicity and resistance in plants. Annu. Rev. Plant Physiol. Plant Mol. Biol. 46:237-260.

Kochian LV, Hoekenga OA, Pineros MA (2004) How do crop plants tolerate acid soils? Mechanisms of aluminum tolerance and phosphorous efficiency. Annu. Rev. Plant Physiol. 55:459-493.

Kuo MC, Kao CH (2003) Aluminum effects on lipid peroxidation and antioxidative enzyme activities in rice leaves. Biol. Plant. 46:149-152.

Lopes AS (1994) Solos sob cerrado. Piracicaba: Associação Brasileira para Pesquisa da Potassa e do Fosfato.

Lowry OH, Rosebrough NJ, Farr AL, Randall RL (1951) Protein measurement with the folin phenol reagent. J. Biol. Chem. 193:265-275.

Ma B, Gao L, Zhang H, Cui J, Shen Z (2012) Aluminum-induced oxidative stress and changes in antioxidant defenses in the roots of rice varieties differing in Al tolerance. Plant Cell Rep. 31:687-696.

Mendonca RJ, Cambraia J, Oliva MA, Oliveira já (2005) Capacidade de cultivares de arroz de modificar o pH de solucoes nutritivas na presenca de aluminio. Pesq. Agropec. Bras. 40:447-452.

Meriga B, Attitalla IH, Ramgopal M, Ediga A, Kavikisshor PB (2000) Diferential tolerance to aluminium toxicity in rice cultivars: involvement of antioxidante enzymes and possible role of aluminium resistant locus. Academic J. Plant Sci. 3:53-63.

Meriga B, Reddy K, Rao KR, Reddy LA, Kishor PBK (2004) Aluminuminduced production of oxygen radicals, lipid peroxidation and DNA damage in seedlings of rice (Oryza sativa). J. Plant Physiol. 161:63-68.

Mohammadi M, Karr AL (2001) Superoxide anion generation in effective and ineffective soybean root nodules. J. Plant Physiol. 158:1023-1029.

Nagalakshmi N, Prasad MNV (2001) Responses of glutathione cycle enzymes and glutathione metabolism to copper stress in Scenedesmus bijugatus. Plant Sci. 160:291-299.

Noctor G, Mhamdi A, Chaouch S, Han Y, Neukermans J, MarquezGarcia B, Queval G, Foyer CH (2012) Glutathione in plants: an integrated overview. Plant Cell Environ. 35:454-484.

Panda SK, Matsumoto $\mathrm{H}$ (2010) Changes in antioxidant gene expression and induction of oxidative stress in pea (Pisum sativum L.) under Al stress. BioMetals 23:753-762.

Peixoto PHP, Cambraia J, Sant'Anna R, Mosquim PR, Moreira MA (2010) Aluminum effects on fatty acid composition and lipid peroxidation of a 
purified plasma membrane fraction of root apices of two sorghum cultivars. J. Plant Nutr. 27:1061-1070.

Peixoto PHP, Cambraia J, Sant'Anna R, Mosquim PR, Moreira MA (1999) Aluminum effects on lipid peroxidation and on the activities of enzymes of oxidative metabolism in sorghum. Rev. Bras. Fisiol. Veg. $11: 137-143$

Pereira LB, Mazzanti CM, Goncalves JF, Cargnelutti D, Tabaldi LA, Becker AG, et al (2010) Aluminum-induced oxidative stress in cucumber. Plant Physiol. Biochem. 48:683-689.

Potters G, De Gara L, Asard H, Horemans N (2002) Ascorbate and glutathione: guardians of the cell cycle, partners in crime? Plant Physiol. Biochem. 40:537-548.

Richards KD, Schott EJ, Sharma YK, Davis KR, Gardner RC (1998) Aluminum induces oxidative stress genes in Arabidopsis thaliana. Plant Physiol. 116:409-418.

Sharma P, Dubey RS (2007) Involvement of oxidative stress and role of antioxidative defense system in growing rice seedlings exposed to toxic concentrations of aluminum. Plant Cell Rep. 26:2027-2038.
Sivaguru M, Paliwal K (1993) Differential aluminum tolerance in some tropical rice cultivars. I. Growth-performance. J. Plant Nutr. 16:1705-1716.

Vitorello VA, Capaldi FR, Stefanuto VA (2005) Recent advances in aluminum toxicity and resistance in higher plants. Braz. J. Plant Physiol. $17: 129-143$

Xu FJ, Li G, Jin CW, Liu WJ, Zhang SS, Zhang YS, et al (2012) Aluminuminduced changes in reactive oxygen species accumulation, lipid peroxidation and antioxidant capacity in wheat root tips. Biol. Plant. 56:89-96.

Wang C, Wood FA (1973) A modified aluminon reagent for the determination of aluminum after $\mathrm{HNO}_{3}-\mathrm{H}_{2} \mathrm{SO}_{4}$ digestion. Can. J. Soil Sci. 53:237-239.

Wang JW, Kao CH (2007) Protective effect of ascorbic acid and glutathione on AICl3-inhibited growth of rice roots. Biol. Plant. 51:493-500.

Yamamoto Y, Kobayashi Y, Devi SR, Rikiishi S, Matsumoto H (2002) Aluminum toxicity is associated with mitochondrial dysfunction and the production of reactive oxygen species in plant cells. Plant Physiol. 128:63-72. 